http://dx.doi.org/10.18778/1508-1117.23.06

Krzysztof Gargula, Wojciech Zajac

\title{
NOWE ZACHOWANIA PRZESTRZENNE NABYWCÓW NIERUCHOMOŚCI MIESZKANIOWYCH W PRZESTRZENIACH ZURBANIZOWANYCH
}

\begin{abstract}
Zarys treści: Celem artykułu jest ustalenie wpływu determinant geoprzestrzennych ${ }^{1}$ na zachowania nabywców nieruchomości mieszkaniowych w przestrzeniach zurbanizowanych. Zachowanie konsumentów na rynku nieruchomości mieszkaniowych zależy w dużej mierze nie tylko od czynników wewnętrznych (nieprzestrzennych) charakteryzujących nieruchomości przede wszystkim od strony funkcjonalno-technicznej, ale również od czynników zewnętrznych (geoprzestrzennych) opisujących główny atut każdej nieruchomości mieszkaniowej, czyli jej lokalizację w strukturze przestrzeni zurbanizowanej. W celu zrealizowania założeń artykułu przeprowadzono badania geostatystyczne na podstawie danych z rynku nieruchomości lokalowych miasta Bytom.
\end{abstract}

Słowa kluczowe: zachowanie przestrzenne, wartość przestrzeni, nieruchomości mieszkaniowe, przestrzeń zurbanizowana, geostatystyka.

\section{Wprowadzenie}

Nabywcy nieruchomości mieszkaniowych to charakterystyczna grupa konsumentów, której zachowanie na rynku ma znaczący wpływ na poziom cen nieruchomości mieszkalnych. Grupa ta jest często poddawana badaniom naukowym. Jednak zazwyczaj są to tzw. ,,badania preferencji”, czyli analizy przeprowadzane na podstawie wyników ankietowych, dzięki którym uzyskuje się jedynie ogólny pogląd na aktualne potrzeby nabywców nieruchomości. Szersze spojrzenie na zachowania nabywców nieruchomości mieszkaniowych można zaobserwować dzięki użyciu do analiz rynku nieruchomości technik i metod statystycznych i geostatystycznych.

\footnotetext{
${ }^{1}$ Determinanty geoprzestrzenne (ang. geospatial data) nieruchomości mieszkaniowych to różnego rodzaju czynniki techniczne, społeczno-ekonomiczne i inne mające wpływ na poziom cen nieruchomości mieszkaniowych, przedstawione w formie danych przestrzennych, tj. map wektorowych lub rastrowych.
} 
Charakterystyczną cechą rynku nieruchomości mieszkalnych jest jego lokalny charakter. Oznacza to, że duży wpływ na dynamikę zmian cen transakcyjnych mają uwarunkowania przestrzenne badanego rynku. Świadomość istnienia zależności przestrzennych na rynku nieruchomości jest powszechna w środowisku zajmującym się wyceną nieruchomości zarówno pod względem praktycznym (zawodowym), jak i teoretycznym (naukowym). Nie zawsze idzie ona w parze z wykorzystaniem odpowiednich metod statystyki przestrzennej czy technik geostatystycznych, które pozwalają badać zachowania na rynku z wykorzystaniem aspektów przestrzennych.

Podczas kupna mieszkania nabywcy zwracają szczególną uwagę na cenę nieruchomości, która jest zazwyczaj głównym czynnikiem decydującym o wyborze mieszkania. Równie duże, o ile nie większe, znaczenie nadaje się innemu czynnikowi, tj. lokalizacji. Nieruchomości mieszkalne są przypisane na stałe do konkretnych miejsc w przestrzeni, czyli charakteryzują się niemobilnością. Niemobilność oznacza, że bliskość elementów otoczenia (najbliższe sąsiedztwo), jak i położenie pod względem innych obiektów lub zjawisk społeczno-ekonomicznych (lokalizacja) są integralną częścią analizowanego mieszkania na równi z cechami fizycznymi (nieprzestrzennymi) nieruchomości. Czynniki otoczenia są zewnętrznymi komponentami mieszkania. W przeciwieństwie do cech wewnętrznych mieszkania (fizycznych), na konsumpcję elementów otoczenia użytkownicy nieruchomości nie mają wyłączności. Otoczenie może generować zarówno pozytywne, jak i negatywne efekty. Do pozytywnych czynników możemy zaliczyć np. bliskość infrastruktury społecznej (przedszkoli, szkół, obiektów sportowych), technicznej, dostępność do usług różnego rodzaju oraz zdywersyfikowany i zasobny rynek pracy, a do negatywnych m.in. uciążliwy hałas, zanieczyszczenie środowiska czy wysoką przestępczość w otoczeniu nieruchomości (Domański 2002; Polko 2005). Determinantami cech nieruchomości mogą być zatem korzyści aglomeracji wynikające z nagromadzenia się na niewielkim obszarze dużej grupy ludzi, jednostek gospodarczych oraz instytucji, a tym samym rozbudowanej infrastruktury (Czornik 2008).

Otoczenie nieruchomości mieszkaniowych w przestrzeniach zurbanizowanych polskich miast w ostatnich czasach coraz częściej poddawane jest zmianom w wymiarze przestrzennym m.in. poprzez procesy rewitalizacji lub gentryfikacji. W wielu publikacjach naukowych (Murzyn 2006; Palicki 2013; Górczyńska 2015) podkreśla się ekonomiczne aspekty przywołanych procesów, które najczęściej przejawiają się w postaci wzrostów średnich cen nieruchomości w obszarze ich przestrzennego oddziaływania. Należy jednak podkreślić fakt, że szybko rosnące ceny w tych przestrzeniach są zazwyczaj napędzane efektem spekulacji inwestorów i nie do końca odzwierciedlają one realny wpływ zmieniającego się otoczenia na ostateczną cenę nieruchomości mieszkaniowych. 
W latach 2009-2013 na poziomie ogólnopolskim można zauważyć wzrost liczby transakcji lokali mieszkalnych z niewielkim spadkiem w roku 2014. Natomiast wartości transakcji kupna/sprzedaży lokali mieszkalnych w latach 2009-2014 rosną, ale od roku 2013 z mniejszą intensywnością. Od 2004 do 2014 przeciętne wynagrodzenie brutto w podmiotach gospodarczych zatrudniających więcej niż 9 osób wykazuje tendencję wzrostową na szczeblu krajowym, w województwie śląskim oraz w Bytomiu. Z drugiej strony zarobki w Bytomiu są mniejsze niż w województwie i w kraju, co źle świadczy o sytuacji gospodarczej miasta ${ }^{2}$.

Zgodnie z analizą wykonaną przez NBP dla siedmiu najważniejszych dużych miast w Polsce (Gdańsk, Gdynia, Kraków, Łódź, Poznań, Warszawa, Wrocław) od roku 2008 potencjalna możliwość zakupu $1 \mathrm{~m}^{2}$ mieszkania za przeciętne wynagrodzenie w sektorze przedsiębiorstw wzrastała. Z drugiej strony stale malejący indeks ZKPK (zakumulowany indeks zmiany kryteriów polityki kredytowej banków) oznacza zaostrzenie polityki kredytowej banków (Łaszek i in. 2015). Reasumując, banki utrudniają uzyskanie kredytów mieszkaniowych, ale fakt, że ludzie zarabiają coraz więcej ułatwia im wzięcie kredytu. Analizy wykonane przez GUS oraz NBP nie tłumaczą jednak, jak czynniki geoprzestrzenne determinują ceny transakcyjne nieruchomości. Dlatego postanowiono przeprowadzić bardziej szczegółową analizę cen transakcyjnych z wykorzystaniem różnych metod analizy przestrzennej na wybranym przykładzie, czyli mieście Bytom.

W przeprowadzonych badaniach skoncentrowano się na przeanalizowaniu zależności jakie zachodzą pomiędzy średnimi cenami nieruchomości mieszkaniowych miasta Bytom a ich geoprzestrzennymi determinantami. Rzetelne badanie prawidłowości występujących na rynku nieruchomości mieszkalnych z uwzględnieniem lokalizacji zarówno zmiennej objaśnianej (cen transakcyjnych lokali mieszkalnych), jak i zmiennych wyjaśniających (determinant geoprzestrzennych) ma znaczący wpływ na jakość i wiarygodność przeprowadzonej analizy.

\section{Opis metod i zastosowanie}

W opracowaniu zastosowano następujące statystyczne (w tym geostatystyczne) metody analizy danych przestrzennych: autokorelację przestrzenną, interpolację przestrzenną, estymator jądrowy gęstości, metodę najmniejszych kwadratów oraz regresję ważoną geograficznie.

Pojęcie autokorelacji przestrzennej wywodzi się z pierwszego prawa geografii W. Toblera (1970) mówiącego o tym, że „wszystko jest związane z wszystkim innym, ale w pobliżu rzeczy są bardziej związane niż rzeczy odległe". Autokorelacja przestrzenna polega na tym, że natężenie zjawisk przestrzennych w jednym miejscu zależne jest od ich natężenia w sąsiednich lub bliskich miejscach (Runge

2 Opracowanie na podstawie Banku Danych Lokalnych GUS, za: Obrót nieruchomościami w 2014, Warszawa. 
2007). Jest to stopień skorelowania wartości zmiennej w danej lokalizacji z wartością tej samej zmiennej w innej lokalizacji (Cellmer 2014). Miary autokorelacji przestrzennej dzieli się na globalne i lokalne. Do globalnych zaliczyć można statystykę globalną I Morana oraz ogólną G Getisa. Do miar lokalnych należą m.in. lokalna statystyka G Getisa. Metody globalne identyfikują autokorelację przestrzenną w odniesieniu do całego systemu, zaś lokalne umożliwiają odnalezienie wzorców lokalnych powiązań (Kopczewska 2011).

Statystykę globalną Morana I wyraża się następującym wzorem:

$$
\begin{gathered}
I=\frac{\sum_{i} * \sum_{j} w_{i j}\left(x_{i}-\bar{x}\right)\left(x_{j}-\bar{x}\right)}{S^{2} \sum_{i} * \sum_{j} w_{i j}} \\
S^{2}=\frac{1}{\mathrm{n}} \sum_{i}\left(x_{i}-x\right)^{2}
\end{gathered}
$$

gdzie:

$x_{i}$ - jest obserwacją w regionie $i$,

$\mathrm{n}-$ jest liczbą regionów,

$w_{i j}$ - jest elementem przestrzennej macierzy wag, która powinna być standaryzowana rzędami do jedynki; jest to waga połączeń między jednostką $i$ oraz $j$.

Statystyka globalna Morana I osiąga wartości w przedziale od -1 do 1. Dodatnia, istotna oraz wysoka wartość wskazuje na podobieństwo obiektów znajdujących się blisko siebie. Ujemna, istotna oraz niska wartość oznacza, że obiekty znajdujące się daleko od siebie są podobne. Zaś wartość bliska zeru jest interpretowana jako brak jakiejkolwiek autokorelacji - losowe rozmieszczenie punktów z wartościami (Kopczewska 2011).

Statystykę ogólną Getisa określa się wzorem:

$$
G(d)=\frac{\sum_{i=1}^{n} * \sum_{j=1}^{n} w_{i j}(d) x_{i} x_{j}}{\sum_{i=1}^{n} * \sum_{j=1}^{n} x_{i} x_{j}}
$$

gdzie wszystkie elementy są interpretowane tak samo jak we wzorze na globalną statystykę Morana I, za wyjątkiem , d", które oznacza maksymalny dystans, w obrębie którego spodziewane jest pojawienie się skupień. Statystyka pozwala badać, czy powstają skupienia wysokich (hot spots) czy też niskich wartości (cold spots) (Cellmer 2014). 
Statystykę lokalną G Getisa oblicza się wzorem:

$$
G_{i}(d)=\frac{\sum_{j=i}^{n} w_{i j}(d) x_{j}}{\sum_{j=i}^{n} x_{j}}
$$

Korzystać ze wzoru można uwzględniając obserwacje z lokalizacji lub też nie (Cellmer 2014). Dodatnie i istotne wartości statystyki G są dowodem na grupowanie się regionów o wysokich wartościach. Analogicznie, ujemne istotne wartości oznaczają istnienie grupy regionów o niskich wartościach (Kopczewska 2011).

Przykładowe badania związane z autokorelacją przestrzenną mogą dotyczyć wielu dziedzin, takich jak: ekologia (Lichstein 2002), genetyka (Rosser 2000), kryminalistyka (Mordwa 2011), dostępność krwiodawstwa (Ojrzyńska, Twaróg 2011) oraz analiza rynku nieruchomości (Kozioł-Kaczorek 2011; Kozioł-Kaczorek, Pietrzykowski 2011; Cellmer 2012, 2013; Widłak i in. 2014). W powyższych publikacjach związanych $\mathrm{z}$ analizą rynku nieruchomości dowiedziono istnienie autokorelacji przestrzennej dodatniej.

Występowanie autokorelacji przestrzennej może stanowić podstawę do wykonania interpolacji przestrzennej. Interpolacja przestrzenna jest to metoda z zakresu analizy przestrzennej pozwalająca przewidzieć wartości na mapie tam, gdzie nie zostały one zmierzone. Jest stosowana najczęściej do tworzenia map wysokościowych, temperatur, opadów, emisji zanieczyszczeń, ponieważ te zjawiska prawie zawsze wykazują autokorelację przestrzenną (Longley i in. 2006). W analizie wykorzystano następujące metody interpolacji przestrzennej: metodę odwrotnych ważonych odległości IDW, metodę radialnych funkcji bazowych RBF oraz Kriging.

Metoda IDW (ang. Inverse Distance Weighting), czyli metoda odwrotnych ważonych odległości polega na przewidywaniu wartości zmiennych jako średniej wagowej z otaczających punktów pomiarowych. Współczynnik wagowy jest odwrotnością odległości. Przypisywane wagi są zatem tym większe im odległość od punktów pomiarowych jest mniejsza. Podstawowym parametrem tej metody interpolacji jest ,power” oznaczający potęgę, do której podniesiona jest odwrotność odległości. Niski „power” tworzy bardziej gładką interpolowaną powierzchnię, z kolei wysoki sprawia, że większe wagi przypisywane są obszarom znajdującym się bliżej punktów pomiarowych. Wartości interpolowane metodą IDW nie mogą przekroczyć wartości minimalnych ani maksymalnych wynikających z dostępnych próbek, co może niedokładnie interpolować powierzchnię na obszarach nieobjętych próbkami pomiarowymi. (Longley i in. 2006; Li, Heap 2008).

Metody interpolacji RBF (ang. Radial Basis Functions), czyli radialne funkcje bazowe - będące rodzajem sztucznych sieci neuronowych - wizualnie przypominają gumowy arkusz rozciągnięty na punktach pomiarowych. Na RBF składa 
się kilka funkcji bazowych różniących się stopniem wygładzenia wynikowej interpolowanej powierzchni. Warto zauważyć, że w przeciwieństwie do IDW metody RBF pozwalają uzyskać rezultaty większe lub mniejsze od analizowanych punktów pomiarowych. Obie metody są wiernymi interpolatorami, co oznacza, że przewidując wartości przechodzą one przez wszystkie punkty pomiarowe nie zmieniając jednocześnie ich wartości (Longley i in. 2006; Cichociński 2011).

Kriging jest jedną z najbardziej złożonych metod interpolacji przestrzennej. Przed interpolacją wykonuje się semiwariogram „będący funkcją opisującą stopień zróżnicowania danych w zależności od odległości między nimi” (Urbański 2012). Podobnie jak w metodzie IDW, wartości obliczane są jako średnie ważone z otaczających punktów pomiarowych, ale dodatkowo uwzględniany jest także kierunek, w jakim względem siebie punkty pomiarowe są podobne oraz parametry ustalone w semiwariogramie (Longley in. 2006). Wykres semiwariogramu na osi pionowej przedstawia wartość semiwariancji będącej miarą zróżnicowania, z kolei na osi poziomej odzwierciedlone są przedziały odległości, w jakich badane jest podobieństwo par punktów (lags). Do parametrów semiwariogramu należą range (zasięg), sill (próg) oraz nugget (podstawa). Range określa odległość pomiędzy badanymi parami punktów, gdy wykres funkcji semiwariogramu przechodzi w próg. Natomiast sill definiuje maksymalną wysokość funkcji semiwariogramu, zaś nugget podnosi początek funkcji do określonej wysokości (Li, Heap 2008).

Estymator jądrowy gęstości jest wykorzystywany do modelowania wygładzonej powierzchni przedstawiającej gęstość wynikającą z koncentracji punktów w otaczającym obszarze. Przykładowo metodę tę można stosować do konstrukcji map prezentujących m.in. natężenie ruchu ulicznego, liczebność transakcji, intensywność zabudowy. Miarę tę wyraża się wzorem (Cellmer 2014):

$$
\hat{f}(x)=\frac{1}{m h^{n}} \sum_{i=1}^{m} K\left(\frac{x-x_{i}}{h}\right)
$$

gdzie:

$m$ - liczebność próby losowej,

$n$ - wymiary przestrzeni,

$h$ - dodatnia liczba rzeczywista (parametr wygładzania),

$K$ - funkcja spełniająca następujące warunki:

$$
\begin{gathered}
\int_{R^{n}} K(x) d x=1 \\
K(x)=K(-x) \forall x \in R^{n} \\
K(0) \geq K(x)
\end{gathered}
$$


Metoda najmniejszych kwadratów (ang. OLS - Ordinary Least Squares) „to metoda estymacji parametrów strukturalnych modelu regresji zapisanego w postaci addytywnej, która pozwala na znalezienie takich ocen tych parametrów, że suma kwadratów odchyleń pomiędzy rzeczywistymi a teoretycznymi wartościami zmiennej objaśnianej jest najmniejsza" (Kot i in. 2007).

Konstrukcja modelu OLS wiąże się z koniecznością spełnienia pewnych warunków, takich jak (Charlton, Fotheringham 2013):

- odpowiednio wysoki współczynnik determinacji określający, w jakim stopniu zmienne objaśniające wyjaśniają wartość zmiennej objaśnianej, im bliższy 1 tym lepiej,

- niska wartość kryterium informacji Akaike określającego relatywny dystans pomiędzy dopasowanym a nieznanym prawdziwym modelem,

- wskaźnik inflacji wariancji mniejszy niż 7,5. Wartość przekraczająca 7,5 oznacza powtarzalność danych,

- nieistotna statystycznie wartość statystyki Jarque-Bera świadcząca o normalnym rozkładzie dla reszt,

- nieistotna statystyka Konkera (BP) świadcząca o braku heteroskedastyczności, w przypadku istotności tej statystyki należy sprawdzić, czy tzw. „robust probability" dla zmiennych są istotne statystycznie,

- istotne statystyki Joint F oraz Walda wskazujące na ogólne znaczenie modelu, jeżeli statystyka Konkera (BP) jest nieistotna, to wtedy jedynie statystyka Walda jest wiarygodna,

- brak autokorelacji przestrzennej reszt modelu,

- istotność statystyczna zmiennych objaśniających.

Metoda geograficznie ważonej regresji (ang. GWR - geographically weighted regression) przypomina metodę najmniejszych kwadratów, ale dodatkowo uwzględnia czynnik lokalizacji. Wyraża się wzorem (Widłak i in. 2014):

$$
\mathrm{y}_{\mathrm{i}}=\beta_{i 0}\left(\mathrm{u}_{i}, \mathrm{v}_{i}\right)+\sum_{k} * \beta_{i k}\left(\mathrm{u}_{i}, \mathrm{v}_{i}\right) \mathrm{x}_{i k}+\varepsilon_{i}
$$

gdzie:

$\mathrm{y}_{i}$ - zmienna zależna,

$\left(\mathrm{u}_{i}, \mathrm{v}_{i}\right)$ - szerokość i długość geograficzna,

$\beta_{i k}\left(\mathrm{u}_{i}, \mathrm{v}_{i}\right)$ - realizacja $\beta_{k}(\mathrm{u}, \mathrm{v}) \mathrm{w}$ punkcie , $i$ " w przestrzeni, $\varepsilon_{i}$ - błąd.

Regresję ważoną geograficznie stosowano m.in. w badaniu cech rozmieszczenia sklepów w przestrzeni wielkomiejskiej na przykładzie Wrocławia (Ilnicki i in. 2011), do analizy czynników kształtujących zapotrzebowanie na świadczenia przedszpitalnego ratownictwa medycznego (Kisiała 2013), w analizie hedonicznej cen domów Warszawy (Widłak i in. 2014), w przestrzennej analizie wtórnego rynku 
mieszkaniowego Warszawy (Chrzanowska 2011), w analizie zależności pomiędzy ceną a lokalizacją nieruchomości na przykładzie Krakowa (Branna 2012), w analizie przestrzennej lokalnego rynku nieruchomości Olsztyna (Cellmer 2012).

\section{Wykorzystanie danych w postępowaniu badawczym}

W przeprowadzonym badaniu skoncentrowano się na wykryciu zależności występujących pomiędzy średnimi cenami transakcyjnymi nieruchomości w mieście Bytom a ich rozmieszczeniem w przestrzeni zurbanizowanej. Wybór obszaru był zdeterminowany dostępnością danych zarówno nieprzestrzennych m.in. Rejestr Cen i Wartości Nieruchomości, jak i przestrzennych (szeroka baza danych Wydziału Geodezji). Miasto Bytom jest charakterystycznym miastem³ ${ }^{3}$ w którym w ostatnich latach autorzy w ramach innych badań zaobserwowali ciekawe procesy przestrzenne, m.in. wzmacniający się podział przestrzeni miasta na dwie części, tj. słabszą wschodnią i mocniejszą zachodnią pod względem atrakcyjności inwestycyjnej w wymiarze inwestycji mieszkaniowych. Cześć północno-zachodnia miasta charakteryzuje się dynamicznym rozwojem budownictwa mieszkaniowego w ostatnich latach. Jednak należy podkreślić, że zjawisko to opiera się głównie na budownictwie jednorodzinnym. Sytuacja ta może wskazywać, że zamożniejsza ludność miasta przenosi się na obrzeża, gdzie może znaleźć wymarzone miejsce na dom (Gargula 2014). Z kolei najkorzystniejsze tereny pod rewitalizację ze względu na korzyści aglomeracyjne oraz nagromadzenie pustostanów zlokalizowane są w Śródmieściu, czyli części wschodniej (Zając 2015). Obserwowane zjawiska przejawiające się w przestrzeni miasta skłoniły autorów do podjęcia się przedmiotowego tematu naukowego.

Skuteczność analiz w dużym stopniu zależy od dostępności danych wejściowych, na co zwracają uwagę również inni naukowcy zajmujący się tematyką nieruchomości. Autorzy w badaniu wykorzystali udostępnione dane z RCiWN miasta Bytom w formie zestawienia tabelarycznego za lata 2010 i 2014. Dane te zostały przekształcone $\mathrm{w}$ dane przestrzenne poprzez proces tzw. geokodowa-

\footnotetext{
${ }^{3}$ Miasto to zostało uznane na szczeblu krajowym i regionalnym za tzw. obszar strategicznej interwencji, dzięki czemu Bytom pozyska dodatkowe środki pozakonkursowe w wysokości ok. 100 mln euro w ramach RPOWSL 2014-2020. Trudną sytuację Bytomia zaznaczono w treści programu RPOWSL 2014-2020 - „wśród miast Unii Europejskiej z największymi problemami społecznymi, spośród których najszybciej się wyludniającymi są Bytom i Sosnowiec. Szczególnie w Bytomiu, oprócz wysokiego bezrobocia, występują znaczne szkody górnicze, które powodują m.in. zawalenia budynków, a także postępuje wyludnienie i dekapitalizacja budynków w centrum miasta. Wsparcie obszarów wymagających rewitalizacji zostanie skoncentrowane na ośrodkach o największym natężeniu problemów społecznych, gospodarczych i infrastrukturalnych, którymi są w szczególności Bytom oraz funkcjonalnie powiązany z nim Radzionków (będący niegdyś dzielnicą Bytomia)", za: www.bytom.pl/obszar-strategicznej-interwencji (dostęp: 10.09.2015).
} 
nia. Nadawanie odniesienia przestrzennego poszczególnym transakcjom odbyło się poprzez połączenie (klucz = identyfikator lokalu) danych z RCiWN z przestrzenną bazą danych budynków i punktów adresowych miasta (EGiB). Następnie przygotowane dane zostały poddane procedurze redukcji w celu usunięcia danych odstających i nieistotnych.

Pod uwagę brane były tylko transakcje lokali o funkcji mieszkalnej z wolnego rynku, gdzie sprzedającym i kupującym była osoba fizyczna. Dane ograniczono również pod względem ilości izb (przyjęto przedział od 2 do 6), wielkości powierzchni lokalu (przyjęto przedział od $20 \mathrm{do} 120 \mathrm{~m}^{2}$ ) oraz poziomu ceny za $1 \mathrm{~m}^{2}$ (przyjęto przedział od 1000 do $3500 \mathrm{zł} / \mathrm{m}^{2}$ ). Zabiegi te miały na celu ujednolicenie lokalnego rynku nieruchomości. Dodatkowo powstałą bazę danych poddano analizie semiwariogramem, dzięki któremu zniwelowano zbiór danych o transakcje odstające od grup tworzących skupiska przestrzenne pod względem ceny wyrażonej w zł/ $/ \mathrm{m}^{2}$. W końcowym rozrachunku uzyskano 317 w 2010 roku i 354 w 2014 roku unikalnych transakcji sprzedaży nieruchomości mieszkaniowych w Bytomiu.

Następnie zbadano autokorelację przestrzenną cen transakcyjnych dla przyjętych przedziałów czasowych metodą globalną i lokalną. Badania te są podstawą wykonania interpolacji przestrzennej danych. W analizie przetestowano trzy najpopularniejsze metody interpolacji przestrzennej, tj. metodę IDW, RBF oraz Kriging. Po uzyskaniu wyników analiz geostatystycznych porównano powyższe metody i wybrano tą, której wynik (mapa interpolowanych średnich cen nieruchomości) był najdokładniejszy w założonym obszarze przestrzennym.

W kolejnym etapie badania wykorzystano dane planistyczne miasta Bytom, tj. aktualny dokument Studium Uwarunkowań i Kierunków Zagospodarowania Przestrzennego w celu ustalenia zasięgu przestrzennego potencjalnych terenów, na których znajduje się lub będzie znajdować się zabudowa mieszkaniowa wielorodzinna. Na podstawie obszarów określonych w kierunkach zagospodarowania przestrzennego miasta jako „S1 - tereny zabudowy śródmiejskiej” i „M2 - tereny zabudowy mieszkaniowej wielorodzinnej" stworzono poligonową siatkę kwadratów o boku $100 \mathrm{~m}^{4}$. Wyliczony obszar w warstwie poligonowej (siatce kwadratów) uznano za główny obszar badawczy analiz przestrzennych.

W kolejnej części badania ustalono średnie ceny transakcyjne nieruchomości mieszkaniowych $\left(\mathrm{z} / \mathrm{m}^{2}\right)$ wykorzystując w tym celu uprzednio stworzoną siatkę kwadratów. Dla każdego oczka siatki obliczono średnią wartość cen transakcyjnych nieruchomości mieszkaniowych na podstawie wybranej interpolowanej mapy cen transakcyjnych.

${ }^{4}$ Długość 100 m jest równa 1 minucie pieszego spaceru, co według autorów jest adekwatnym obszarem dla szacowania średnich cen transakcyjnych nieruchomości mieszkaniowych. 
W badaniu, oprócz danych z RCiWN, wykorzystano również gotowe dane przestrzenne udostępnione przez Wydział Geodezji Urzędu Miasta Bytom. Dodatkowo wykorzystano wybrane dane z ogólnodostępnej bazy danych projektu Open Street Map. Na podstawie powyższych danych stworzono zestaw determinant geoprzestrzennych nieruchomości mieszkalnych. W tym zestawie umieszczono klasyczne zmienne określone dwiema kategoriami, tj. infrastrukturą techniczną, m.in.: bliskość dróg lokalnych, dróg tranzytowych, terenów przemysłowych, natężenie średnioroczne hałasu i inne; oraz infrastrukturą społeczną, m.in.: bliskość przedszkoli, szkół, handlu, terenów zielonych, sportowo-rekreacyjnych i inne. Dodatkowo przetestowano nowatorski zestaw zmiennych określony jako grupa problemów lokalnych i społecznych, w której znalazły się m.in. zmienne, tj. rozmieszczenie bezrobocia, lokali socjalnych, klientów korzystających z pomocy Miejskiego Ośrodka Pomocy Rodzinie czy przestępczości. Wartości zmiennych były szacowane trzema metodami statystyki przestrzennej: metodą najbliższej odległości od obiektu, gęstości skupień lub wskaźnika udziału w powierzchni.

W końcowym etapie autorzy przeanalizowali stworzone determinanty geoprzestrzenne i ich wpływu na średnie ceny transakcyjne nieruchomości mieszkaniowych. W tym celu zbadano znaczenie korelacji zmiennych ze średnimi cenami nieruchomości z poszczególnych lat. Następnie przeprowadzono badanie regresji liniowej metodą najmniejszych kwadratów (OLS) oraz regresji ważonej geograficznie (GWR).

\section{Wyniki badań}

Globalna statystyka I Morana dla 317 cen nieruchomości z 2010 roku wyniosła ok. 0,3. Natomiast dla 354 cen nieruchomości z 2014 roku współczynnik ten wyniósł ok. 0,36. Obie metody zastosowano uwzględniając odwrotne odległości kwadratowe, co w rezultacie przypisywało większe wagi nieruchomościom zlokalizowanym blisko siebie. Ceny kupowanych nieruchomości mają zatem umiarkowaną tendencję do tworzenia skupisk o podobnych wartościach. Statystyka ogólna G Getisa wykazała losowe rozmieszczenie cen nieruchomości, więc nie można na jej podstawie stwierdzić, czy są to skupiska wysokich czy niskich wartości.

By dogłębniej przeanalizować podobieństwo cen nieruchomości posłużono się lokalną miarą autokorelacji przestrzennej. Zastosowanie lokalnej statystyki G Getisa na danych z 2010 i 2014 roku dowiodło występowania skupisk o wysokich wartościach nieruchomości (hot spots) w peryferyjnych dzielnicach oraz skupisk niskich wartości (cold spots) w centrum (Śródmieściu). W 2014 roku niskie ceny nieruchomości znajdujących się blisko siebie odnotowano na większym obszarze Śródmieścia oraz w dzielnicach Łagiewniki i Rozbark. Istniejące duże skupiska wysokich wartości nieruchomości w dzielnicach obrzeżnych wydają się rozrastać, zaś małe mają tendencję do zanikania (rys. 1 i 2). 


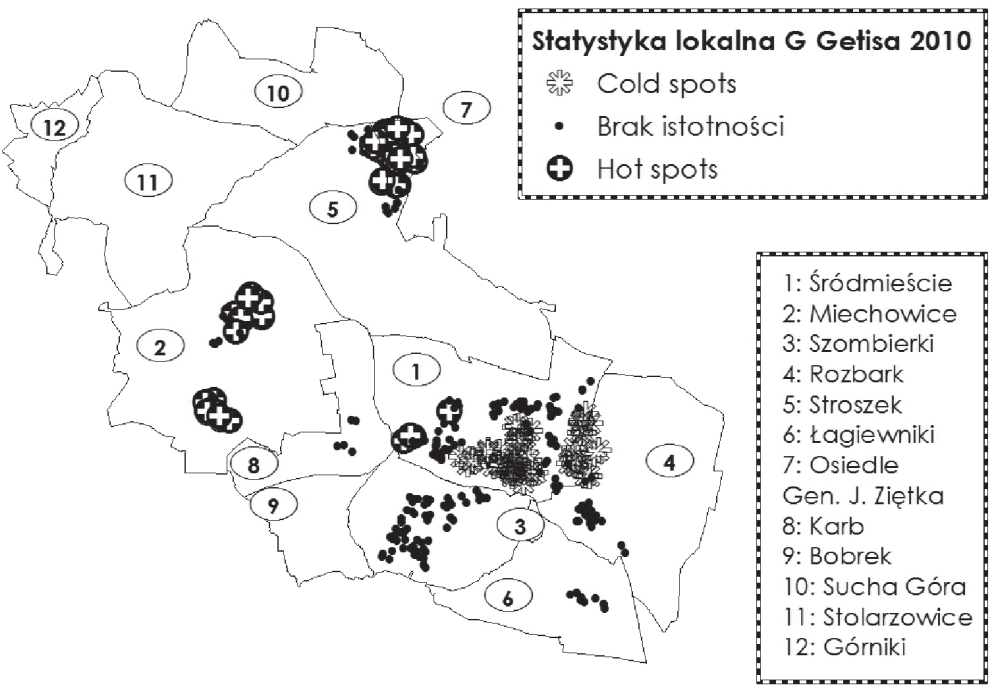

Rys. 1. Statystyka lokalna G Getisa dla ceny transakcyjnej za $1 \mathrm{~m}^{2}$ lokalów mieszkalnych z roku 2010 w Bytomiu

Źródło: opracowanie własne na podstawie danych udostępnionych przez Urząd Miejski w Bytomiu

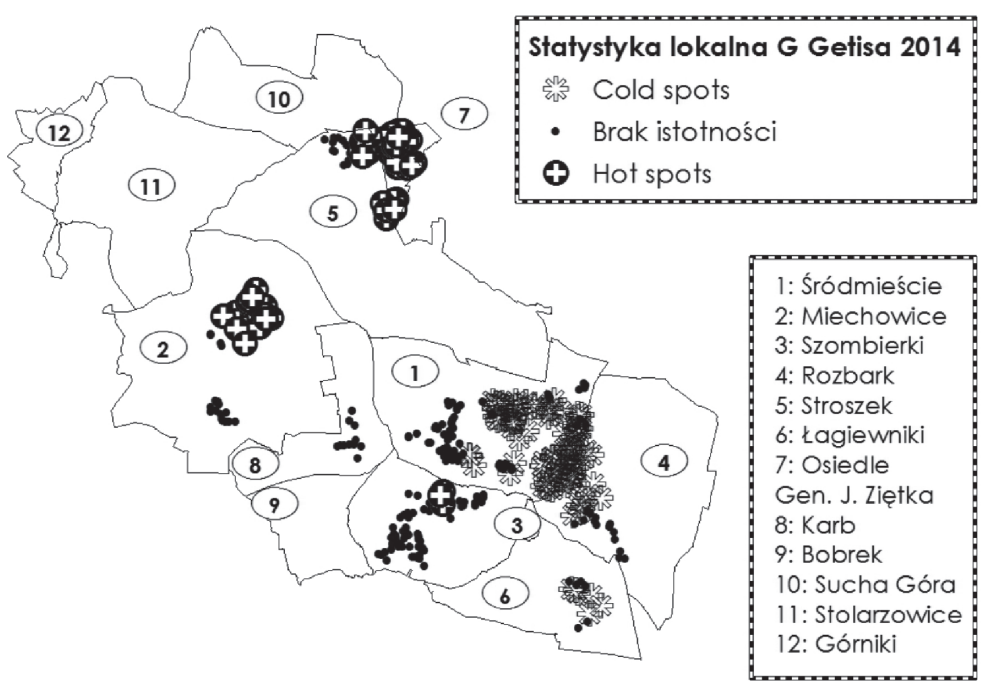

Rys. 2. Statystyka lokalna G Getisa dla ceny transakcyjnej za $1 \mathrm{~m}^{2}$ lokalów mieszkalnych z roku 2014 w Bytomiu

Źródło: opracowanie własne na podstawie danych udostępnionych przez Urząd Miejski w Bytomiu 
Wartość autokorelacji przestrzennej dodatniej świadczy o umiarkowanej zmienności cen nieruchomości, co daje podstawę do zastosowania metod interpolacji przestrzennej.

Wykonano w sumie trzy interpolacje przestrzenne, ale najmniejszy średni błąd miał miejsce w przypadku Krigingu, więc to właśnie tę interpolację wybrano jako bazę do przeprowadzenia analizy regresji. Wyniki interpolacji przestrzennej rozciągnięto do jednego spójnego przedziału, aby były one wizualnie porównywalne. Po wizualizacji cen metodą Krigingu zauważyć można wyraźny spadek wartości kupowanych nieruchomości mieszkaniowych na całym obszarze przeznaczonym pod mieszkalnictwo (rys. 3 i 4).

W 2014 roku kupujący średnio wydawali mniej na lokale mieszkalne, ale $\mathrm{z}$ drugiej strony ceny były bardziej zróżnicowane (tab. 1).

Tabela 1

Statystyki opisowe dla cen transakcyjnych nieruchomości mieszkaniowych w latach 2010 i 2014

\begin{tabular}{|c|c|c|c|c|c|c|c|c|c|}
\hline \multirow{2}{*}{$\begin{array}{c}\text { Zmien- } \\
\text { na }\end{array}$} & \multicolumn{6}{|c|}{ Statystyki opisowe dla cen transakcyjnych nieruchomości w latach 2010 oraz 2014} \\
\cline { 2 - 10 } & Średnia & $\begin{array}{c}\text { Media- } \\
\text {-na }\end{array}$ & $\begin{array}{c}\text { Mini- } \\
- \text { mum }\end{array}$ & $\begin{array}{c}\text { Maksi- } \\
\text { mum }\end{array}$ & $\begin{array}{c}\text { Warian- } \\
\text { cja }\end{array}$ & $\begin{array}{c}\text { Odch. } \\
\text { stan- } \\
\text { dard. }\end{array}$ & $\begin{array}{c}\text { Współ. } \\
\text { zmien- } \\
\text { ności }\end{array}$ & $\begin{array}{c}\text { Skoś- } \\
\text { ność }\end{array}$ & Kurtoza \\
\hline 2010 & 2241.06 & 2252.24 & 1657.35 & 2686.70 & 42974.64 & 207.30 & 9.25 & -0.4435 & -0.3060 \\
\hline 2014 & 1960.56 & 1951.28 & 1366.38 & 2865.39 & 54817.35 & 234.13 & 11.94 & 0.4382 & 0.8177 \\
\hline
\end{tabular}

Źródło: opracowanie własne na podstawie danych udostępnionych przez Urząd Miejski w Bytomiu.

Przygotowując dane do przeprowadzenia analizy regresji metodą najmniejszych kwadratów zbadano je pod kątem korelacji ze zmienną zależną, czyli cenami transakcyjnymi za $1 \mathrm{~m}^{2} \mathrm{w}$ roku 2010 oraz 2014.

Ceny transakcyjne nieruchomości w 2010 i 2014 roku były najbardziej skorelowane z odległością od rynku, odległością od zakładów utylizacji i składowisk odpadów oraz odległością od miejsc lokalizacji zwłok. Istotna korelacja z ostatnią z wymienionych zmiennych może budzić wątpliwości, ale ze względu na brak takich przykładów w literaturze postanowiono uwzględnić tą zmienną w analizie. Na cenę transakcyjną lokali mieszkaniowych nie miały większego wpływu hałas, odległość od dróg, odległość od terenów zielonych, odległość od miejsc kradzieży rowerów oraz kilka innych czynników (tab. 2). 


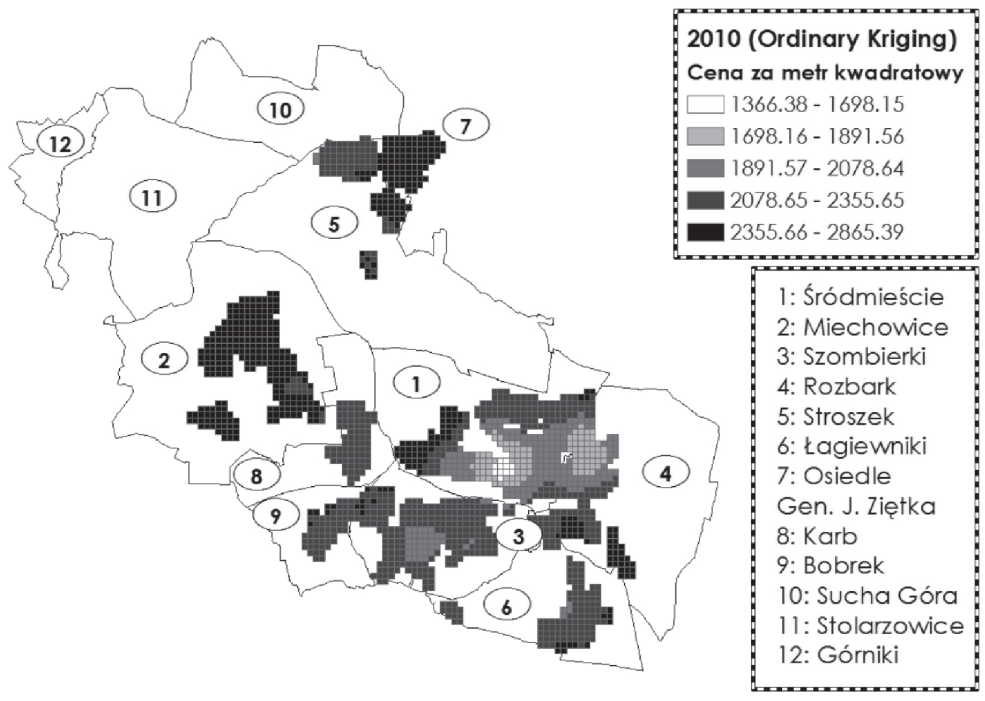

Rys. 3. Interpolacja przestrzenna (Ordinary Kriging) cen transakcyjnych lokali mieszkalnych z 2010 roku w Bytomiu

Źródło: opracowanie własne na podstawie danych udostępnionych przez Urząd Miejski w Bytomiu

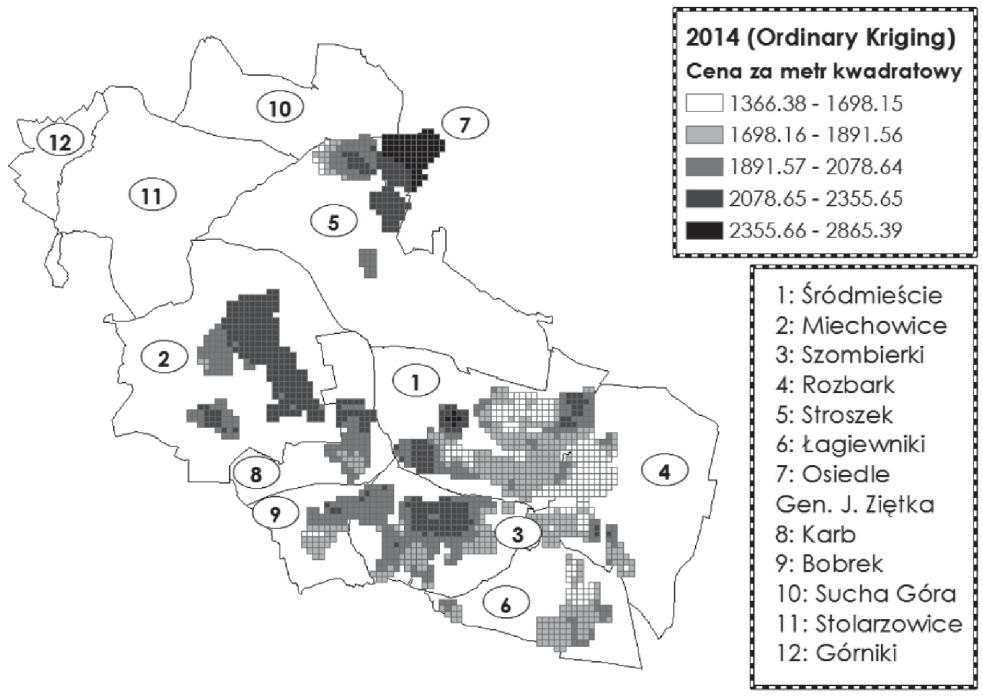

Rys. 4. Interpolacja przestrzenna (Ordinary Kriging) cen transakcyjnych lokali mieszkalnych z 2014 roku w Bytomiu

Źródło: opracowanie własne na podstawie danych udostępnionych przez Urząd Miejski w Bytomiu 
Tabela 2

Współczynniki korelacji cen nieruchomości mieszkaniowych z roku 2010 i 2014

\begin{tabular}{|c|c|c|}
\hline \multirow{2}{*}{ Zmienna } & \multicolumn{2}{|c|}{ Współczynnik korelacji } \\
\hline & Ceny 2010 & Ceny 2014 \\
\hline Odległość od ulic & 0.173799 & 0.059438 \\
\hline Odległość od dróg tranzytowych & 0.211265 & 0.069140 \\
\hline Odległość od terenów kopalni & 0.400842 & 0.300109 \\
\hline Hałas & -0.047764 & -0.103084 \\
\hline Odległość od przedszkoli & 0.268131 & 0.049327 \\
\hline Odległość od szkół podstawowych & 0.324968 & 0.251242 \\
\hline Odległość od małych jednostek handlowych & 0.437473 & 0.300355 \\
\hline Odległość od supermarketów & 0.154640 & -0.032692 \\
\hline Odległość od parków & 0.026160 & 0.073624 \\
\hline Odległość od ogródków działkowych & 0.071261 & 0.285686 \\
\hline Udział parkingu w powierzchni obszaru & -0.065502 & 0.045558 \\
\hline Udział trawy w powierzchni obszaru & -0.023527 & -0.021219 \\
\hline Odległość od rynku & 0.685925 & 0.629630 \\
\hline Odległość od cmentarzy & 0.503097 & 0.379712 \\
\hline Odległość od posterunków policji & 0.254775 & 0.016335 \\
\hline Odległość od dróg rowerowych & -0.137300 & -0.100077 \\
\hline Odległość od zbiorników wodnych & -0.012147 & 0.181490 \\
\hline Odległość od obiektów gastronomicznych & 0.211385 & 0.052380 \\
\hline Odległość od banków & 0.321669 & 0.065371 \\
\hline Odległość od przystanków & 0.147114 & 0.142568 \\
\hline Odległość od oczyszczalni & -0.443798 & -0.595034 \\
\hline Odległość od składowisk odpadów & 0.643639 & 0.638111 \\
\hline Odległość od obiektów sportowych & -0.225260 & -0.241979 \\
\hline Odległość od zakładów utylizacji & 0.609235 & 0.653933 \\
\hline $\begin{array}{l}\text { Odległość od zakładów utylizacji oraz składowisk } \\
\text { odpadów }\end{array}$ & 0.622778 & 0.640071 \\
\hline Gęstość bezrobocia & -0.670764 & -0.438811 \\
\hline Gęstość lokali socjalnych & -0.215283 & -0.237306 \\
\hline $\begin{array}{l}\text { Gęstość klientów korzystających z MOPR (ubóstwo, } \\
\text { przemoc i alkoholizm) }\end{array}$ & -0.637057 & -0.484932 \\
\hline Gęstość ubóstwa & -0.634721 & -0.483669 \\
\hline Gęstość przemocy & -0.609556 & -0.391448 \\
\hline
\end{tabular}


Tabela 2 (cd.)

\begin{tabular}{|l|c|r|}
\hline \multicolumn{2}{|c|}{ Zmienna } & \multicolumn{2}{c|}{ Współczynnik korelacji } \\
\cline { 2 - 3 } & Ceny 2010 & Ceny 2014 \\
\hline Gęstość alkoholizmu & $\mathbf{- 0 . 5 5 9 9 7 7}$ & -0.447972 \\
\hline $\begin{array}{l}\text { Odległość od lokalizacji zwłok (prawdopodobnie } \\
\text { niebezpieczne miejsca) }\end{array}$ & $\mathbf{0 . 4 9 9 6 6 0}$ & $\mathbf{0 . 5 2 9 7 0 1}$ \\
\hline Gęstość zaludnienia 2010 & $\mathbf{- 0 . 5 4 4 6 9 5}$ & -0.208359 \\
\hline Gęstość zaludnienia 2014 & $\mathbf{- 0 . 5 4 0 5 5 7}$ & -0.209291 \\
\hline Odległość od miejsc kradzieży rowerów & 0.078361 & -0.059073 \\
\hline Odległość od pustostanów & 0.428245 & $\mathbf{0 . 5 5 2 5 4 4}$ \\
\hline
\end{tabular}

Źródło: opracowanie własne na podstawie danych udostępnionych przez Urząd Miejski w Bytomiu.

W procesie konstrukcji równań regresji przetestowano jedynie zmienne, które były w odpowiednim stopniu skorelowane ze zmiennymi objaśnianymi, czyli cenami transakcyjnymi z roku 2010 oraz 2014. Zmienne, które powinny mieć duży wpływ na cenę nieruchomości, takie jak bliskość przystanków czy supermarketów musiały zostać wykluczone ze względu na niski współczynnik korelacji.

Za pomocą OLS odnaleziono równanie regresji, które spełniło prawie wszystkie wymagania kluczowe dla realizacji metody najmniejszych kwadratów, poza brakiem autokorelacji przestrzennej reszt. Równanie uzyskane metodą OLS dla roku było następujące:

Cena za $1 \mathrm{~m}^{2}$ w $2010=2212.982285+(-6.250511) *$ gęstość przemocy - $0.388126 *$ gęstość bezrobocia $+4.397877 *$ gęstość alkoholizmu +0.040010 * odległość od rynku + 0.101556 * odległość od miejsca znalezienia zwłok.

Współczynnik determinacji dla tego równania był wysoki, przez zmienne objaśniające zostało wyjaśnione ok. 63\% wartości ceny transakcyjnej za $1 \mathrm{~m}^{2}$ nieruchomości. Największy wpływ na cenę nieruchomości mieszkalnej w 2010 roku miała gęstość przemocy. Im częściej dochodziło do przemocy, tym niższe odnotowywano ceny nieruchomości. Najmniejszy wpływ na cenę miała odległość od historycznego rynku rozumianego jako centralny plac Bytomia. $\mathrm{Z}$ powodu wystąpienia autokorelacji przestrzennej reszt, przeprowadzono analizę regresji ważonej geograficznie z tymi samymi zmiennymi, uzyskując wyższy współczynnik determinacji o wartości 0,76. Duże wartości odchylenia standardowego reszt w centrum świadczą o tym, że w tych miejscach ceny są większe niż to, co przewidział model, zaś wartości niskie, które również dominują w Śródmieściu pokazują miejsca, gdzie ceny są analogicznie mniejsze niż wskazywałby uzyskany model (rys. 5). 


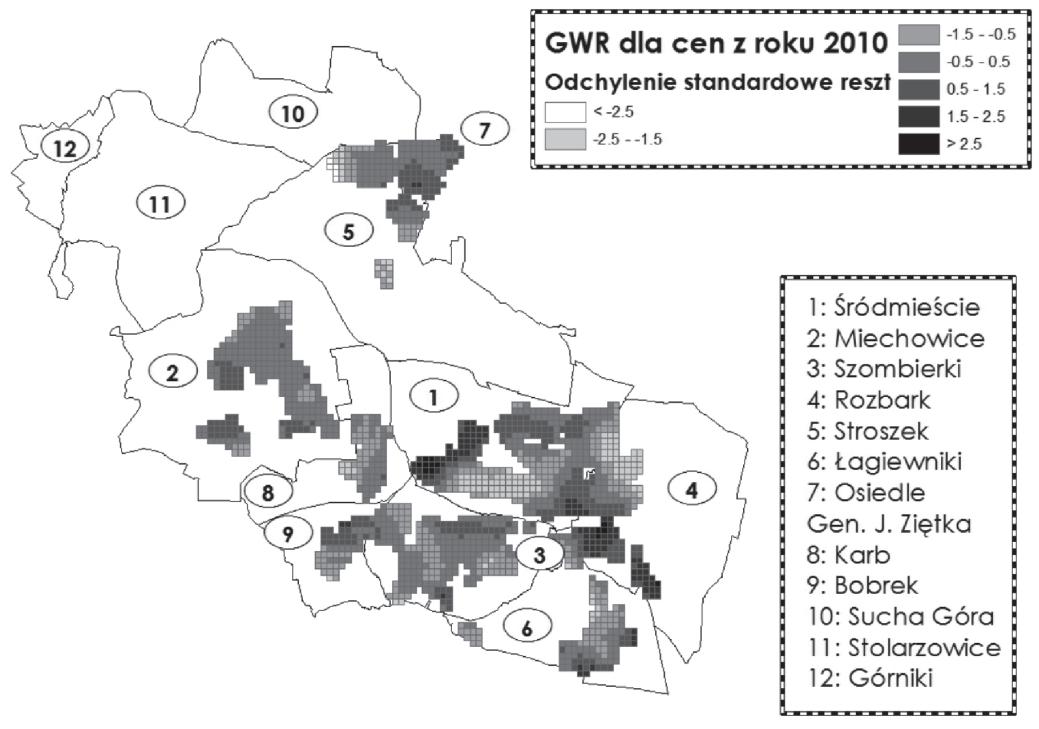

Rys. 5. Analiza GWR dla cen transakcyjnych za $1 \mathrm{~m}^{2}$ lokalu mieszkalnego w 2010 roku w Bytomiu

Źródło: opracowanie własne na podstawie danych udostępnionych przez Urząd Miejski w Bytomiu

Co ciekawe, ten sam model dla roku 2014 okazał się być nieistotny statystycznie, co świadczy o zmieniających się zachowaniach przestrzennych kupujących lokale mieszkalne w Bytomiu. Autorzy nie potrafili jednak odnaleźć pasującego oraz istotnego statystycznie modelu.

\section{Podsumowanie i wnioski}

Konstrukcja modeli regresji dla zachowań przestrzennych kupujących nieruchomości mieszkaniowe jest dużym wyzwaniem wynikającym z konieczności spełnienia wielu warunków zapewniających istotność statystyczną wyników. By to osiągnąć należy przetestować wiele wskaźników, które niekoniecznie muszą prowadzić do racjonalnych wyników. Okazuje się, że korzyści aglomeracji związane z tworzeniem się skupisk działalności gospodarczej, infrastruktury i usług nie mają większego wpływu na ceny nieruchomości. Dużo większe znaczenie mają czynniki związane z niekorzystnym oddziaływaniem otoczenia. W uzyskanym modelu regresji wzrost przemocy oraz bezrobocia, bliskość lokalizacji miejsc znalezienia zwłok wpływają negatywnie na cenę, co tłumaczyć można obawami kupujących przed miejscami niebezpiecznymi. Jednak duży dodatni współczynnik regresji został przypisany występowaniu alkoholizmu - wraz ze wzrostem 
jego przestrzennej gęstości rosną ceny nieruchomości. Może to być przypadek, ponieważ alkoholizm jest zwykle utożsamiany z patologiami społecznymi, które są postrzegane negatywnie. Wzrost wartości nieruchomości mieszkaniowych wraz z oddalaniem się od rynku jest charakterystycznym efektem w miastach poprzemysłowych, które zazwyczaj posiadają zdegradowaną tkankę miejską w przestrzeniach śródmiejskich. Miasto Bytom jest modelowym przykładem takich miast. Jednak w badanym przypadku średnie ceny nieruchomości mieszkaniowych w niektórych obszarach dzielnicy Śródmieście rosną w przeciwieństwie do ogólnego spadku cen w mieście. Sytuacja ta może stanowić o tym, że wspomniana tkanka miejska przechodzi pozytywny proces renowacji zabudowy mieszkalnej, a mieszkańcy miasta coraz chętniej wracają do mieszkań zlokalizowanych w centrum miasta. W analizowanym czasie miasto Bytom realizowało projekty inwestycyjne związane z rewitalizacją śródmieścia, które obecnie są kontynuowane - jest to jeden z głównych priorytetów polityki miejskiej Bytomia, który mógł mieć bezpośredni wpływ na powyższy efekt na badanym rynku nieruchomości. Trudność z uzyskaniem poprawnego równania regresji dla roku 2014 może świadczyć o nieracjonalnym zachowaniu kupujących bądź też przykładaniu większej wagi do innych, np. nieprzestrzennych czynników. Innym powodem może być też duże odchylenie standardowe reszt w centrum, co dowodzi, że analiza w tym miejscu była najmniej wiarygodna.

\section{LITERATURA}

Branna J., 2012, Analiza zależności pomiędzy cena a lokalizacja nieruchomości na przykladzie Krakowa, „Roczniki Geomatyki - Annals of Geomatics”, 10 (4/54), Kraków, s. 29-40.

Cellmer R., 2012, Spatial Analysis of Local Real Estate Market Activity - the Example of the City of Olsztyn, „Studia i Materiały Towarzystwa Naukowego Nieruchomości”. Topical Issues in the Valuation and Application of Market Value, Olsztyn, s. 77-88.

Cellmer R., 2013, Use of Spatial Autocorrelation to Build Regression Models of Transaction Prices, „Studia i Materiały Towarzystwa Naukowego Nieruchomości”, 21(4), Olsztyn, s. 65-74.

Cellmer R., 2014, Modelowanie przestrzenne w procesie opracowywania map wartości gruntów, Wydawnictwo Uniwersytetu Warmińsko-Mazurskiego, Olsztyn.

Charlton M., Fotheringham A.S., 2013, Geographically Weighted Regression: A Tutorial on Using GWR in Arc GIS 9.3, National Centre for Geocomputation, National University of Ireland Maynooth, Manuscript.

Chrzanowska M., 2011, Przestrzenna analiza warszawskiego (wtórnego) rynku mieszkaniowego, ,Studia i Materiały Towarzystwa Naukowego Nieruchomości”, 19(3), Olsztyn, s. $170-180$.

Cichociński P., 2011, Porównanie metod interpolacji przestrzennej w odniesieniu do wartości nieruchomości, „Studia i Materiały Towarzystwa Naukowego Nieruchomości”, 19(3), Olsztyn, s. 120-129. 
Ciesiółka P., 2016, Gentryfikacja jako efekt rewitalizacji. Przykład Poznania, http://www. urbanistyka.info/content/gentryfikacja-jako-efekt-rewitalizacji-przyk\%C5\%82ad-poznania (dostęp: 17.03.2016).

Czornik M., 2008, Miasto. Ekonomiczne aspekty funkcjonowania, Wydawnictwo Akademii Ekonomicznej im. K. Adamieckiego w Katowicach, Katowice.

Domański R., 2002, Gospodarka przestrzenna, PWN, Warszawa.

Gargula K., 2014, Ocena zagospodarowania przestrzennego Bytomia pod względem atrakcyjności inwestycyjnej, Uniwersytet Ekonomiczny w Katowicach, praca magisterska, Katowice.

Górczyńska M., 2015, Gentryfikacja w polskim kontekście: krytyczny przeglad koncepcji wyjaśniajacych, „Przegląd Geograficzny”, IGiPZ PAN, Warszawa, s. 589-611.

Ilnicki D., Janc K., Kryza M., Szymanowski M., 2011, Cechy rozmieszczenia sklepów w przestrzeni wielkomiejskiej na przyktadzie Wrocławia - zastosowanie regresji ważonej geograficznie, [w:] Ekonometria przestrzenna i regionalne analizy ekonomiczne, „Acta Universitatis Lodziensis. Folia Oeconomica”, 253, Łódź, s. 253-268.

Kisiała W., 2013, Wykorzystanie geograficznie ważonej regresji do analizy czynników ksztaltujacych zapotrzebowanie na świadczenia przedszpitalnego ratownictwa medycznego, „Przegląd Geograficzny”, 85, IGiPZ PAN, Warszawa, s. 2.

Kopczewska K., 2011, Ekonometria i statystyka przestrzenna z wykorzystaniem programu $R$ CRAN, CeDeWu Wydawnictwa Fachowe, Warszawa.

Kot S.M., Jakubowski J., Sokołowski A., 2007, Statystyka: podręcznik dla studiów ekonomicznych, Centrum Doradztwa i Informacji Difin, Warszawa.

Kozioł-Kaczorek D., 2011, Statystyka Morana $w$ analizie rozkładu cen nieruchomości, „Metody Ilościowe w Badaniach Ekonomicznych”, XII-2, Warszawa, s. 222-231.

Kozioł-Kaczorek D., Pietrzykowski R., 2011, Analiza cen nieruchomości z wykorzystaniem statystyki Morana, „Studia i Materiały Towarzystwa Naukowego Nieruchomości”, 19(3), Olsztyn, s. 182-191.

Li J., Heap A.D., 2008, A review of spatial interpolation methods for environmental scientists, Geoscience Australia, Canberra.

Lichstein J.W., 2002, Spatial autocorrelation and autoregressive models in ecology, „Ecological Monographs", 72(3), s. 445-463.

Longley P.A., Goodchild M.F., Maguire D.J., Rhind D.W., 2006, GIS. Teoria i praktyka, PWN, Warszawa.

Łaszek J., Augustyniak H., Olszewski K., Waszczuk J., 2015, Informacja o cenach mieszkań i sytuacji na rynku nieruchomości mieszkaniowych $i$ komercyjnych $w$ Polsce w IV kwartale 2014 roku, NBP, Warszawa.

Mordwa S., 2011, Kradzieże w przestrzeni Łodzi, „Acta Universitatis Lodziensis. Folia Geographica Socio-Oeconomica”, 11, Wydawnictwo UŁ, Łódź.

Murzyn M.A., 2006, Kazimierz. Środkowoeuropejskie doświadczenie rewitalizacji, Międzynarodowe Centrum Kultury, Kraków.

Obrót nieruchomościami w 2014, 2015, GUS, Warszawa.

Ojrzyńska A., Twaróg S., 2011, Badanie autokorelacji przestrzennej krwiodawstwa w Polsce, [w:] Ekonometria przestrzenna i regionalne analizy ekonomiczne, „Acta Universitatis Lodziensis. Folia Oeconomica”, 253, Łódź, s. 129-141.

Palicki S., 2013, Rewitalizacja a rynek nieruchomości mieszkaniowych. Przypadek poznańskie Środki, Wydział Prawa i Administracji UAM, Poznań, s. 209-229. 
Polko A., 2005, Miejski rynek mieszkaniowy i efekt sąsiedztwa, Wydawnictwo Akademii Ekonomicznej im. K. Adamieckiego w Katowicach, Katowice.

Rosser Z.H., 2000, Y-Chromosomal Diversity in Europe is Clinal and Influenced Primarily by Geography, Rather than by Language, ,The American Journal of Human Genetics", 67(6), s. 1526-1543.

Runge J., 2007, Metody badań w geografii społeczno-ekonomicznej: elementy metodologii, wybrane narzędzia badawcze, Wydawnictwo Uniwersytetu Śląskiego, Katowice.

Tobler W., 1970, A Computer Movie Simulating Urban Growth in the Detroit Region, „Economic Geography”, 46(2), s. 234-240.

Urbański J., 2012, GIS w badaniach przyrodniczych, Wydawnictwo Uniwersytetu Gdańskiego, Gdańsk.

Widłak M., Waszczuk J., Olszewski K., 2014, Spatial and hedonic analysis of house price dynamics in Warsaw, NBP Working Paper, 197, Warszawa.

Zając W., 2015, Wykorzystanie systemów informacji geograficznej do lokalizacji najlepszych terenów pod realizacje projektów rewitalizacji w Bytomiu, [w:] Brandenburg H., Sekuła P. (red.), Projekty lokalne $i$ regionalne. Rola kompetencji w zarzadzaniu projektami, Wydawnictwo Uniwersytetu Ekonomicznego w Katowicach, Katowice, s. 191-204.

\title{
NEW SPATIAL BEHAVIORS OF RESIDENTIAL PROPERTIES PURCHASERS IN URBAN SPACES
}

\begin{abstract}
The article's goal is to determine an impact of geospatial factors on a behavior of residential properties purchasers in urban spaces. The behavior of real estates market consumers doesn't depend mostly only on internal non-spatial factors which characterize functional-technical real estates features. Most of all it depends on the external geospatial factors which describe the major asset of any real estate - its location in the spatial urban structure. The geostatistical analysis of Bytom city residential property was carried out to reach the article's goal. The methods used in the article consisted of testing spatial autocorrelation (Global Moran I, General G Getis, Local G Getis) spatial interpolation, namely: Inverse Distance Weighting (IDW) interpolation, Radial Basis Functions (RBF) and Ordinary Kriging. The authors tested the impact of many geospatial factors such as the proximity to roads, green areas, the density of the poverty, location of banks and many more on the transaction prices of residential properties. The tools used for that were the Ordinary Least Squares (OLS) and the Geographically Weighted Regression (GWR). The finally constructed model consisted of such factors as the density of violence, the unemployment density, the alcoholism density, the market square proximity and the location of dead bodies.
\end{abstract}

Key words: spatial behavior, space value, residential, urbanized space, geostatistics.

Mgr Krzysztof Gargula Mgr Wojciech Zając

Katedra Gospodarki Przestrzennej Wydział Ekonomii, Uniwersytet Ekonomiczny w Katowicach 